Article

\title{
Impacts of Climate Change and Intensive Lesser Snow Goose (Chen caerulescens caerulescens) Activity on Surface Water in High Arctic Pond Complexes
}

\author{
T. Kiyo F. Campbell ${ }^{1}$ (D), Trevor C. Lantz ${ }^{1, *}$ and Robert H. Fraser ${ }^{2}(\mathbb{D}$ \\ 1 School of Environmental Studies, University of Victoria, Victoria, BC V8P 5C2, Canada; tkcampbell@uvic.ca \\ 2 Canada Centre for Mapping and Earth Observation, Natural Resources Canada, Ottawa, ON K1A 0E4, \\ Canada; robert.fraser@canada.ca \\ * Correspondence: tlantz@uvic.ca; Tel.: +1-250-853-3566
}

Received: 20 October 2018; Accepted: 18 November 2018; Published: 27 November 2018

check for updates

\begin{abstract}
Rapid increases in air temperature in Arctic and subarctic regions are driving significant changes to surface waters. These changes and their impacts are not well understood in sensitive high-Arctic ecosystems. This study explores changes in surface water in the high Arctic pond complexes of western Banks Island, Northwest Territories. Landsat imagery (1985-2015) was used to detect sub-pixel trends in surface water. Comparison of higher resolution aerial photographs (1958) and satellite imagery (2014) quantified changes in the size and distribution of waterbodies. Field sampling investigated factors contributing to the observed changes. The impact of expanding lesser snow goose populations and other biotic or abiotic factors on observed changes in surface water were also investigated using an information theoretic model selection approach. Our analyses show that the pond complexes of western Banks Island lost $7.9 \%$ of the surface water that existed in 1985. Drying disproportionately impacted smaller sized waterbodies, indicating that climate is the main driver. Model selection showed that intensive occupation by lesser snow geese was associated with more extensive drying and draining of waterbodies and suggests this intensive habitat use may reduce the resilience of pond complexes to climate warming. Changes in surface water are likely altering permafrost, vegetation, and the utility of these areas for animals and local land-users, and should be investigated further.
\end{abstract}

Keywords: tundra ponds; Arctic wetlands; desiccation; Landsat; aerial photographs; global change; protected areas

\section{Introduction}

Recent temperature increases in Arctic regions have been twice the average global change $[1,2]$ and have triggered significant changes to regional hydrological systems, including surface water dynamics [3-7]. Changes in surface waters are concerning, because lakes, ponds, and wetlands strongly influence a range of physical, geochemical, and biological processes [8-11]. Arctic freshwater systems are also tied to the global climate system through their effects on permafrost thaw and greenhouse gas emissions from thawed ground [12-14].

Changes in the abundance and surface area of lakes and ponds in the Arctic have been attributed to increasing evaporation [15], fluctuations in precipitation [16], permafrost degradation leading to lateral and subsurface drainage $[3,6,17,18]$, and thermokarst lake expansion [19]. The vulnerability of waterbodies to these processes depends on both the waterbody dimensions $[20,21]$ and catchment characteristics $[7,22,23]$. Regional differences in these factors have resulted in considerable variation in surface water dynamics across the Arctic $[7,18,23,24]$. Several recent studies suggest that permafrost 
extent is a major determinant of change in surface water [7,23]. Most studies in discontinuous permafrost zones have reported decreases in surface water, while most studies in continuous permafrost zones have shown increases in surface water $[17,19,23,25]$. However, these studies have been restricted to subarctic and low Arctic regions, and trends in the high Arctic remain largely unstudied.

High Arctic pond complexes may be particularly vulnerable to the effects of increasing air and ground temperatures [26,27]. Small and shallow waterbodies, with high surface area to volume ratios, are disproportionately impacted by fluctuations in evaporation [15,21]. In addition, the shallow active layer common in the high Arctic restricts groundwater storage capacity, reducing resilience during unusually dry periods [28]. Furthermore, the high ground-ice content typically found in regularly saturated soils [28] makes areas more susceptible to thermokarst induced changes to hydrology $[10,29,30]$.

Changes in the extent of surface water in high Arctic pond complexes will likely impact surrounding vegetation and herbivore populations, particularly migratory bird species that use these areas as breeding habitat [11,31]. Pond complexes fill an important ecological niche in the otherwise arid polar deserts of the high Arctic. However, high grazing pressures from expanding herbivore populations could also be contributing to climate-driven changes in surface water. Lesser snow goose (Chen caerulescens caerulescens) nesting colonies across the Arctic have seen rapid expansions in recent decades, largely due to intensified agricultural land-use providing abundant forage in their southern wintering areas and a warming climate in Arctic nesting areas [32]. These expanding nesting colonies have caused significant and lasting degradation to northern wetlands [31,33-35]. Intensive and recurring foraging can alter microtopography [36] and increase near-surface ground temperatures and evaporation $[34,37]$, which likely decreases water retention in nearby waterbodies and may increase the risk of lateral drainage [38]. Park [38] found that ephemeral ponds surrounded by high levels of lesser snow goose grubbing had significantly shorter hydroperiods than ponds not associated with grubbing.

To improve our ability to predict the long-term impacts of climate change on high Arctic freshwater systems, additional case studies are required to understand the processes controlling surface water dynamics. The objectives of this study are to (1) explore the extent of changing waterbodies within the pond complexes of western Banks Island, Northwest Territories; and (2) to investigate the causes of this change. Landsat imagery (1985-2015) was used to detect long-term surface water trends, while higher resolution aerial photographs (1958) and satellite imagery (2014) were used to explore changes in the size and distribution of waterbodies, and field sampling investigated potential causes and contributing factors.

We tested three specific hypotheses: (1) The number and size of waterbodies on western Banks Island is decreasing; (2) the loss of small waterbodies is widespread; and (3) changes in number and size of waterbodies are following different trajectories in heavily overgrazed snow goose nesting areas, compared to areas less impacted by overgrazing.

\section{Materials and Methods}

\subsection{Study Area}

Banks Island is the westernmost island in the Canadian Arctic Archipelago and part of the Inuvialuit Settlement Region in the Northwest Territories. The community of Sachs Harbour is the only permanent settlement on the Island and has a population of approximately 100 residents. Located within the high Arctic, this area has a harsh climate with a mean annual temperature of $-12.8^{\circ} \mathrm{C}$ at Sachs Harbour. Summers are short with average daily temperatures rising above freezing for only 3 months of the year, peaking at $6.6^{\circ} \mathrm{C}$ in July. Average annual precipitation is $151.5 \mathrm{~mm}$, with only $38 \%$ falling as rain (June to September). Mean annual temperatures have shown a $3.5^{\circ} \mathrm{C}$ increase since 1956 , while summer precipitation and maximum snow water equivalent before spring melt have changed minimally $[30,39]$. 
The western side of Banks Island is underlain by unconsolidated Miocene-Pliocene sands and gravels and is characterized by gently rolling uplands, intersected by numerous west-flowing rivers with wide floodplains [40,41]. Alluvial terraces in these river valleys are dotted with thousands of shallow ponds and have nearly continuous vegetation cover, dominated by sedges, grasses, and mosses [31,41]. Decomposition of this vegetation has produced limited organic deposits over predominantly Gleysolic Turbic Cryosols [41]. Permafrost is continuous is this region, and ice-wedge polygons, non-sorted circles and stripes, and turf hummocks are widespread [41]. In this study, we focused on the alluvial terraces of the west-flowing rivers valleys (Figure 1).

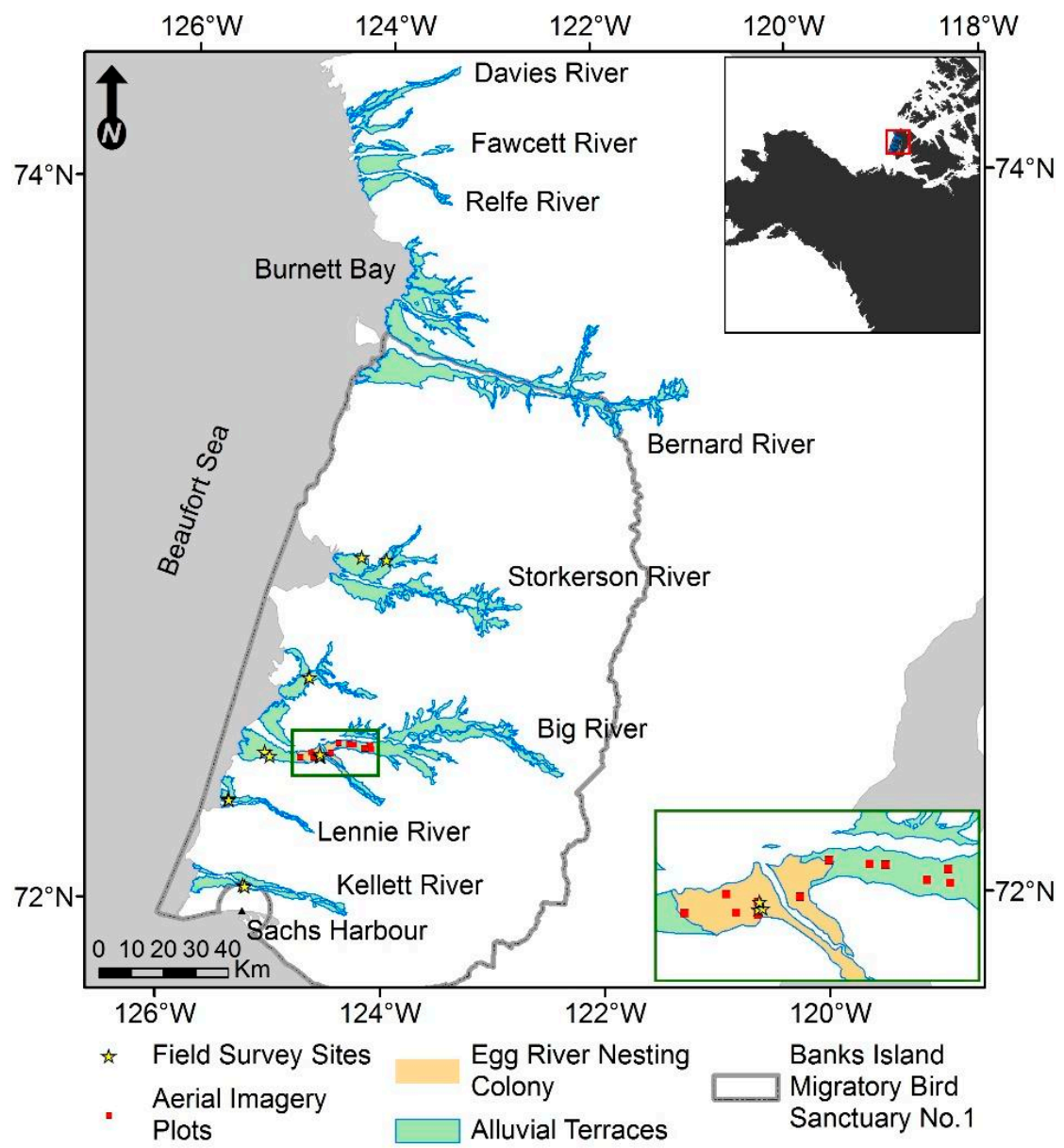

Figure 1. A map of the study area on Banks Island, Northwest Territories, showing field survey sites and areas where fine-scale imagery was analyzed. The inset map in the upper-right corner shows Banks Island as the westernmost island in the Canadian Arctic Archipelago. The inset map in the bottom-right corner is an enlarged map of the nesting colony area, within the Big River valley.

The river valleys of western Banks Island are important breeding habitat for many migratory bird species, including the lesser snow goose. This habitat supports over 95\% of the western Arctic lesser snow goose population. The main nesting colony of this population is located at the confluence of the Egg and Big rivers [31,41] (Figure 1). The Banks Island Migratory Bird Sanctuary No. 1 is the second largest bird sanctuary in Canada at $20,517 \mathrm{~km}^{2}$, and was created to protect this colony [31,41].

\subsection{Sub-Pixel Water Fraction}

To measure persistent changes in surface water, sub-pixel water fraction (SWF) was calculated for 9430 m resolution images captured by the Landsat 5 TM, Landsat 7 ETM+, and Landsat 8 OLI sensors, between 1985 and 2015. Depending on cloud cover, 1 to 7 images were used per year, balanced 
over the time-series so that no significant linear relationship existed with the number of images per year. To minimize the influence of phenology and the spring freshet, all collected images fell within the period of 5 July to 10 August and were balanced across Julian Days so that no significant linear relationship existed over the time-series. Images were calibrated to top-of-atmosphere reflectance using USGS coefficients, and scan lines, clouds, and cloud shadows were masked out [42].

SWF was calculated using the Tasseled Cap wetness (TCW) index, derived from each of the 94 Landsat images, and a histogram-breakpoint method [19]. The TCW index is a transformation that contrasts shortwave infrared with visible and near-infrared bands using established Tasseled Cap (TC) coefficients $[43,44]$. The use of shortwave infrared bands in the TCW index makes it sensitive to water surfaces, soil moisture, and plant moisture [43,45].

Following TCW transformation, breakpoint regression was applied to the frequency distribution of pixel values in each image to identify the land limit (LL), the threshold value separating pure land pixels from pixels of mixed land-water cover, and the water limit (WL), separating pure water pixels from pixels of mixed land-water cover. Breakpoint regression was applied to each scene to reduce variabilities caused by different Landsat sensors, atmospheric conditions, and phenology states. Candidate breakpoints were determined using the 'strucchange' package [46] in R software version 3.3.2 [47] and the breakpoint algorithm for estimating multiple possible breakpoints [48]. Once range limits were obtained, the following equation was used to calculate the SWF of each mixed pixel in an image, where TCW is the Tasseled Cap Wetness value of the pixel being estimated. TCW values outside of the threshold LL and WL values were assigned $0 \%$ or $100 \%$ SWF, respectively.

$$
\mathrm{SWF}=\frac{(\mathrm{TCW}-\mathrm{LL}) \times 100 \%}{(\mathrm{WL}-\mathrm{LL})}
$$

The accuracy of the histogram-breakpoint method in this terrain type was assessed by comparing SWF estimates to manually digitized estimates of surface water within $60\left(0.25 \mathrm{~km}^{2}\right)$ plots in the Big River valley. Manually digitized estimates of surface water were derived from WorldView-2 (WV02) satellite imagery (0.5 m resolution), acquired on 9 July 2014. Because of cloud cover and Landsat 7 scan line errors, the digitized surface water was compared against a multi-year SWF composite, calculated as the mean of SWF images from July 2013 and 2015.

To identify pixels that exhibited persistent changes in surface water, we used Theil-Sen regression and the rank-based Mann-Kendall test to determine SWF trends and significance over time (1985-2015) [19,49]. Theil-Sen regression is a nonparametric alternative to ordinary least-squares regression that uses the median of all possible pairwise slopes instead of the mean. The rank-based Mann-Kendall test of significance is calculated through comparison to all possible pairwise slopes [50]. The change in surface water for pixels with significant trends was estimated by multiplying the slope coefficient by the length of the time-series and the area of a single pixel $\left(900 \mathrm{~m}^{2}\right)$. These changes were then summed within each river valley to estimate regional surface water changes.

This analysis was restricted to the alluvial terraces of major river valleys (an area of $\sim 2335 \mathrm{~km}^{2}$ ), which were manually-delineated as areas of lowland terrain within $25 \mathrm{~km}$ of the main river channel (<80 m above-sea-level) [41]. Lowland terrain was visually identified using $10 \mathrm{~m}$ resolution false-colour near-infrared Sentinel-2 satellite imagery acquired on 19 July 2017, and confirmed using a $5 \mathrm{~m}$ resolution digital elevation model (ArcticDEM) created by the Polar Geospatial Center from DigitalGlobe, Inc. imagery [51].

\subsection{Fine-Scale Surface Water Change Detection}

To explore and corroborate surface water dynamics at a finer scale, the historical and current extent of lakes and ponds was mapped within $12\left(1 \mathrm{~km}^{2}\right)$ plots using greyscale aerial photographs and WV02 satellite images in the Big River valley. Six $\left(1 \mathrm{~km}^{2}\right)$ plots were established in areas impacted by severe drying, and six $\left(1 \mathrm{~km}^{2}\right)$ plots were established in stable areas that were minimally impacted by drying. Severe drying and stable plots were classified based on the composition of significant Local 
Indicators of Spatial Association (LISA) clusters [52] of SWF trends within the Big River valley. Severe drying plots primarily consisted of negative SWF trend clusters (mean $\Delta$ of $-271.5 \mathrm{~m}^{2}$ ) and stable plots primarily consisted of low positive SWF trend clusters (mean $\Delta$ of $+55.6 \mathrm{~m}^{2}$ ). Clusters of negative and positive SWF trends were present in opposing plots; however, they did not exceed $5 \%$ of the plot area. LISA clusters were generated using GeoDa software (1.8.16.4) and an order 2 Queen contiguity weights matrix, including lower orders [52,53].

Historical waterbodies greater than $50 \mathrm{~m}^{2}$ were delineated using 1:60,000 scale aerial photographs acquired on 14 July 1958, with an effective pixel size of $1.5 \mathrm{~m}$. Aerial photographs were georeferenced in ArcMap (10.4.1) using a first-order polynomial transformation and 6-11 control points. The current extent of the waterbodies in these plots was delineated using WV02 satellite imagery ( $0.5 \mathrm{~m}$ resolution) acquired on 9 July 2014. Summer precipitation was similar in 1958 and 2014, reducing the likelihood that interannual variation in precipitation could influence differences in surface water extent. All waterbodies were digitized on-screen while viewing images at a 1:500 scale. If new waterbodies appeared in the 2014 imagery, their historical areas were recorded as zero. A chi-square test was used to determine if the size class distribution of waterbodies in 1958 in severe drying and stable plot types deviated from their expected distribution. Expected values were calculated by multiplying the total number of waterbodies in each size class with the total number in each plot type and dividing by the sample size. Waterbodies were tallied within eight size classes, which progressively doubled in size to account for the lower frequencies of larger waterbodies.

To explore potential drivers of surface water change in the Big River valley, we used an information-theoretic approach to compare models based on four a priori hypotheses regarding the cause of change in the area of individual waterbodies from 1958-2014 [54]. Hypotheses were informed by the literature (Table 1 ) and models were constructed using the linear models procedure in R software (3.3.2) [47]. To account for the greater potential change in surface area of larger sized waterbodies, an interaction term for pond size was also added to several models. The 2015 Tasseled Cap Greenness (TCG) parameter used in models 2 and 3 (Table 1) was calculated using the same methods as for the TCW index [43,44]. The distance from the colony parameter used in models 4 and 5 was $\log$ transformed because visual inspection of the data suggested the relationship was non-linear. The flow accumulation parameter used in models 6 and 7 was calculated using the ArcticDEM [51] and the Fill, Flow Direction, and Flow Accumulation tools on ArcMap (10.4.1). Prior to model selection, all model parameters were examined for outliers using Cleveland dot plots [55] and collinearity using Pearson correlation coefficient matrices. To keep variance inflation factors below 3.0, variable pairs with correlation values greater than 0.7 were not included in the same model $[55,56]$.

Following model selection, we performed an additional analysis using categorical intervals of waterbody size and distance from the nesting colony to better understand how snow goose occupation may be influencing change proportional to the waterbody area. This was conducted using the GLIMMIX procedure in SAS (9.3) to construct a linear mixed effects model of proportional area change versus categorical groupings of waterbody size and distance from the colony [57]. Pairwise comparisons among categories were made using the least-squares procedure, estimated using the restricted-maximum likelihood method. The model included the 12 aerial imagery plots as a random effect. Degrees of freedom were determined using the Kenward-Roger method [57]. 
Table 1. Descriptions of the four a priori hypotheses, parameters included, and model statements. The impact column describes the hypothesized direction of the relationship between the listed parameter and waterbody area change.

\begin{tabular}{|c|c|c|c|c|c|}
\hline Hypothesis & Parameter & Description & Impact (+/-) & Model Number and Statement & Citation \\
\hline $\begin{array}{l}\text { Size: Smaller ponds are more vulnerable to change and } \\
\text { climatic variability, compared to larger ponds. }\end{array}$ & Pond size & $\begin{array}{l}\text { Waterbody extent from the } 1958 \\
\text { aerial photographs. }\end{array}$ & + & (1) Area change $\sim$ Pond size & {$[15,20,21]$} \\
\hline $\begin{array}{l}\text { Vegetation: Vegetation cover insulates near-surface } \\
\text { ground temperatures and increases soil water retention, } \\
\text { sustaining subsurface hydrological connectivity and } \\
\text { reducing system water loss through evaporation. }\end{array}$ & 2015 TCG & $\begin{array}{c}\text { Average TCG value within } \\
0-25 \text { m of the waterbody, taken } \\
\text { from a } 18 \text { July } 2015 \text { Landsat } \\
\text { scene. }\end{array}$ & + & $\begin{array}{c}\text { (2) Area change } \sim 2015 \text { TCG } \\
\text { (3) Area change } \sim 2015 \text { TCG + Pond size } \\
\text { (4) Area change } \sim 2015 \text { TCG + Pond size }+2015 \\
\text { TCG } \times \text { Pond size }\end{array}$ & {$[28,59-62]$} \\
\hline $\begin{array}{l}\text { Herbivore intensity: Intensive and recurring goose } \\
\text { foraging can alter microtopography, and increase soil } \\
\text { temperature and evaporation levels, which may reduce } \\
\text { hydroperiod in nearby waterbodies or increase risk } \\
\text { of drainage. }\end{array}$ & $\begin{array}{l}\text { Colony } \\
\text { distance }\end{array}$ & $\begin{array}{l}\text { Distance from the nesting } \\
\text { colony, which was delineated as } \\
\text { areas of high snow goose } \\
\text { density, using data from } \\
\text { Samelius et al. [58]. }\end{array}$ & + & $\begin{array}{l}\text { (5) Area change } \sim \log (\text { Colony distance }) \\
\text { (6) Area change } \sim \log (\text { Colony distance })+ \\
\text { Pond size } \\
\text { (7) Area change } \sim \log (\text { Colony distance })+\text { Pond } \\
\text { size }+\log (\text { Colony distance }) \times \text { Pond size }\end{array}$ & {$[34,36-38]$} \\
\hline $\begin{array}{l}\text { Surface water connectivity: Drainage areas will have } \\
\text { higher levels of thermal erosion gullying and are more } \\
\text { likely to experience lateral drainage. }\end{array}$ & $\begin{array}{c}\text { Flow } \\
\text { accumulation }\end{array}$ & $\begin{array}{l}\text { Maximum flow level within } \\
25 \mathrm{~m} \text { of the waterbody, based } \\
\text { on the number of upslope } \\
\text { pixels. }\end{array}$ & - & $\begin{array}{l}\text { (8) Area change } \sim \text { Flow accumulation } \\
\text { (9) Area change } \sim \text { Flow accumulation }+ \\
\text { Pond size } \\
\text { (10) Area change } \sim \text { Flow accumulation }+ \text { Pond } \\
\text { size }+ \text { Flow accumulation } \times \text { Pond size }\end{array}$ & [63] \\
\hline
\end{tabular}




\subsection{Field Surveys}

To characterize field conditions in areas that showed declines in SWF and explore potential causes of these changes, surveys were conducted at 13 sites within five river valleys in July 2017 (Figure 1). Field sites were selected using LISA clusters of SWF trends and included drying sites, within clusters of negative SWF trends, and control sites, within clusters of low positive SWF trends and areas outside of significant clusters. We also visited several colony sites that were located within clusters of negative SWF trends, within $1 \mathrm{~km}$ of the densest parts of the nesting colony [58]. Colony sites were sampled to differentiate drying patterns in highly-used snow goose habitat areas from areas not intensively used by snow geese. All sampling locations were selected within the alluvial terraces, between 0-20 m in elevation.

At each site, 11 measurement points were established at $10 \mathrm{~m}$ intervals along a north-south oriented $100 \mathrm{~m}$ transect. At each point, measurements were made of thaw depth, soil moisture, vegetation cover, and goose grubbing. Thaw depth was measured using an active layer probe, which was pushed into the ground until the depth of refusal. Soil moisture was measured using a handheld moisture probe (HH2 Moisture Meter with a Theta Probe soil moisture sensor-ML2x, from Delta-T Devices Ltd., Cambridge, UK). Vegetation cover was measured by visually estimating the percent cover of vascular plants within a $50 \mathrm{~cm}^{2}$ quadrat, aligned with the bottom-left corner at the measurement point. Goose grubbing was measured by counting the number of grub holes within the same $50 \mathrm{~cm}^{2}$ quadrat. Grubbing is a particularly destructive form of foraging which targets below-ground roots and rhizomes before above-ground vegetation is available. Along each transect, we also noted if points were located within a former pond basin. Former pond basins were identified based on the absence of organic material within a pond-shaped topographic depression.

To test for significant differences in thaw depth, soil moisture, vegetation cover, and goose grubbing among drying, control, and colony site types, we constructed linear mixed effects models using the GLIMMIX procedure in SAS (9.3) [57]. Pairwise comparisons among site types were made using the least-squares procedure, estimated using the restricted-maximum likelihood method. All models included site and river valley as random effects. Degrees of freedom were determined using the Kenward-Roger method [57]. Measurements that landed within former pond basins were excluded from statistical comparisons of these variables, as they represented landcover with a different origin and substrate.

\section{Results}

\subsection{Sub-Pixel Water Fraction}

\subsubsection{SWF Trends}

Between 1985 and 2015, the alluvial terraces of western Banks Island lost $33.3 \mathrm{~km}^{2}$ of surface water and gained $3.9 \mathrm{~km}^{2}$ of surface water, resulting in a net loss of $29.3 \mathrm{~km}^{2}$, or $7.9 \%$ of the original surface water (Figures A1-A3). Regional SWF trends indicate that surface water has declined in all river valleys except the Kellett (Figure 2). The Bernard River valley lost the largest absolute area of surface water $\left(8.83 \mathrm{~km}^{2}\right)$ and the Relfe-Fawcett River valley lost the highest proportion of original surface water $(17.1 \%)$. 


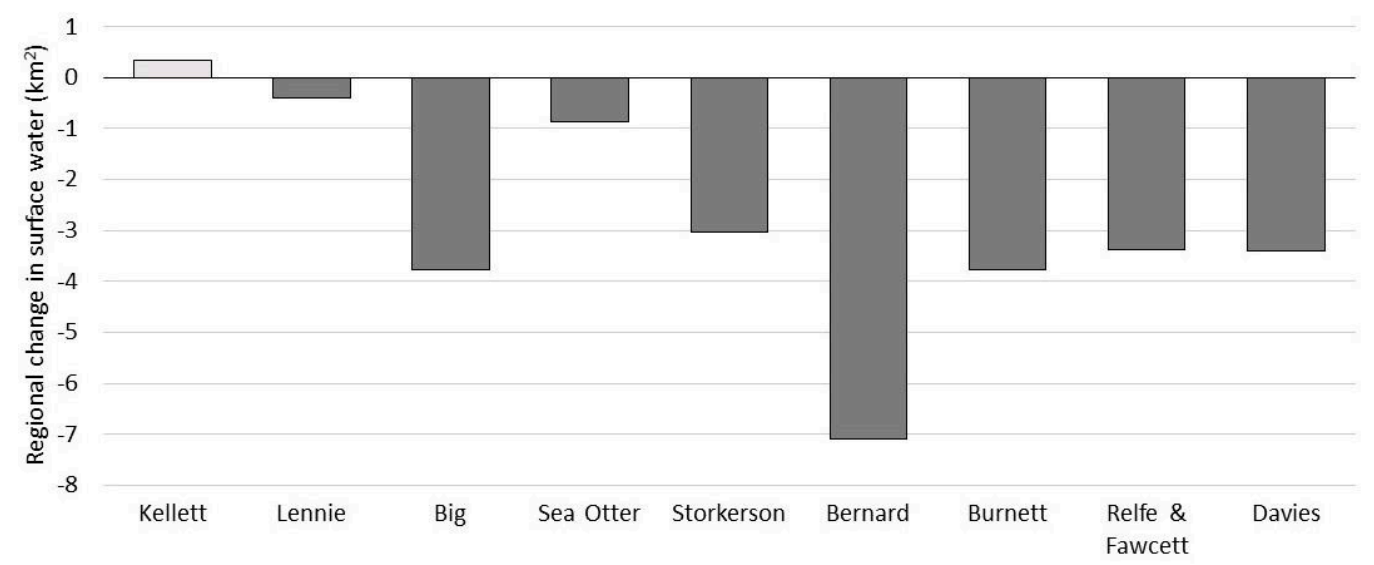

Figure 2. Net change in surface water from 1985-2015 in the 9 major river valleys of western Banks Island. River valleys are ordered by latitude, with the Kellett (at left) being the most southern and the Davies (at right) being the most Northern. SWF trends $(p<0.05)$ were determined using 94 Landsat images between 1985-2015.

\subsubsection{SWF Accuracy}

Estimates of SWF made using the histogram-breakpoint method were strongly correlated with waterbody areas delineated manually. An ordinary least-squares regression model of the sum of SWF pixel values and the sum of manually-delineated waterbody areas within the 60 accuracy assessment plots produced an $\mathrm{r}^{2}$ value of 0.942 and a residual standard error of 0.0124 (Figure 3). In our study, the histogram-breakpoint SWF method overestimated surface water in $83.3 \%$ of the accuracy assessment plots (Figure 3). On average, SWF calculations overestimated waterbody area by $0.00863 \mathrm{~km}^{2}(14 \%)$ compared to manually-delineated waterbody areas. The consistency of overestimation across a range of surface water proportions suggests that it is not likely to have impacted the slopes of SWF trends across the time-series (1985-2015). Overestimation is likely linked to the sensitivity of TCW to plant moisture $[43,45]$ and the occurrence of wet sedge meadows on the landscape, which would not have been delineated as waterbodies using the aerial imagery.

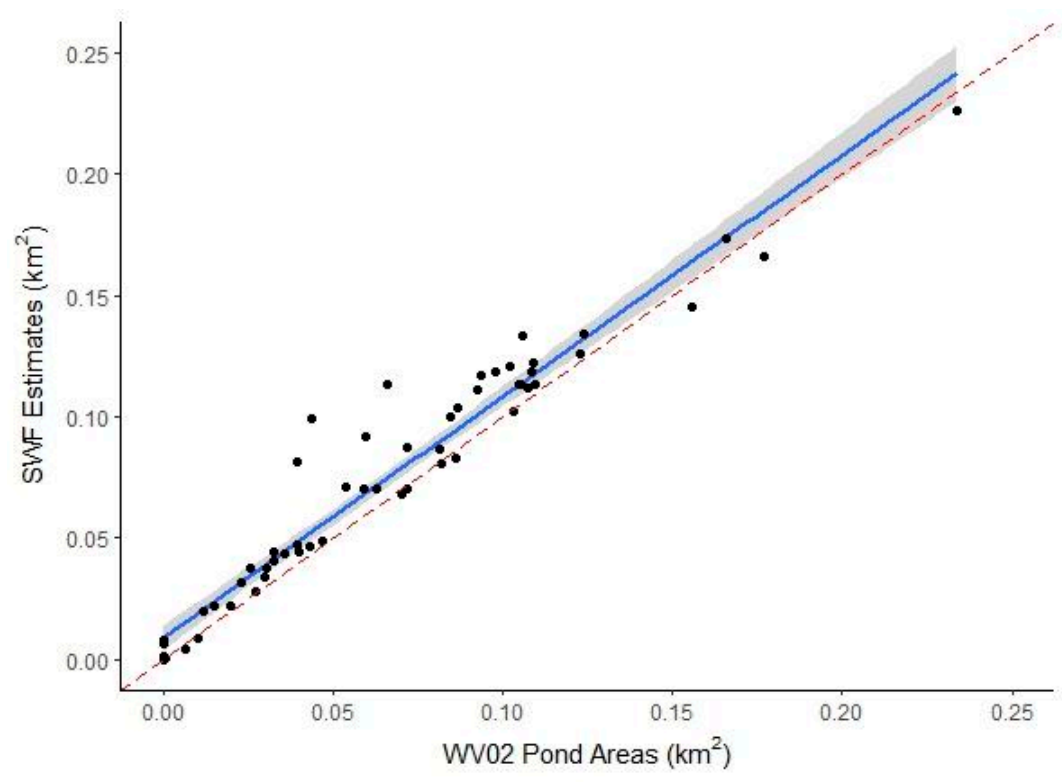

Figure 3. The sum of sub-pixel water fraction pixel values plotted against the sum of the area of manually-delineated waterbodies within $500 \mathrm{~m}^{2}$ plots. The blue line represents the model predictions (SWF estimates $\sim$ WV02 Pond Areas), the grey bar represents the 95\% confidence interval, and the dotted red line shows a 1:1 relationship. 


\subsection{Fine-Scale Surface Water Change Detection}

\subsubsection{Waterbody Size Distributions}

There were large reductions in the number of waterbodies between 1958 and 2014, in both severe drying and stable plots (Figure 4). Severe drying plots exhibited a complete loss of 732 (48.1\%) waterbodies, while stable plots lost 286 (38.1\%) waterbodies. Lost waterbodies ranged in their original size, from $58.5 \mathrm{~m}^{2}$ to $17,708.5 \mathrm{~m}^{2}$. Only 12 new waterbodies were recorded in the 2014 imagery, and only $19.9 \%$ of all waterbodies either increased in surface area or remained stable $(-10 \%$ to $+10 \%$ change).

Severe drying and stable plots exhibited differences in waterbody density and average size. In 1958, severe drying plots had a mean density of 253 waterbodies per $\mathrm{km}^{2}$ and a mean waterbody size of $1228.2 \mathrm{~m}^{2}$. Stable plots had a mean density of 149 waterbodies per $\mathrm{km}^{2}$ and a much larger mean waterbody size of $3319.2 \mathrm{~m}^{2}$. The chi-square test $(p<0.001)$ confirmed that areas exhibiting severe drying had more small waterbodies (50-900 $\left.\mathrm{m}^{2}\right)$ and fewer large waterbodies $\left(>900 \mathrm{~m}^{2}\right)$ than expected. Conversely, stable areas had fewer small waterbodies (50-900 $\left.\mathrm{m}^{2}\right)$ and more large waterbodies $\left(>900 \mathrm{~m}^{2}\right)$ than expected (Table 2 ).

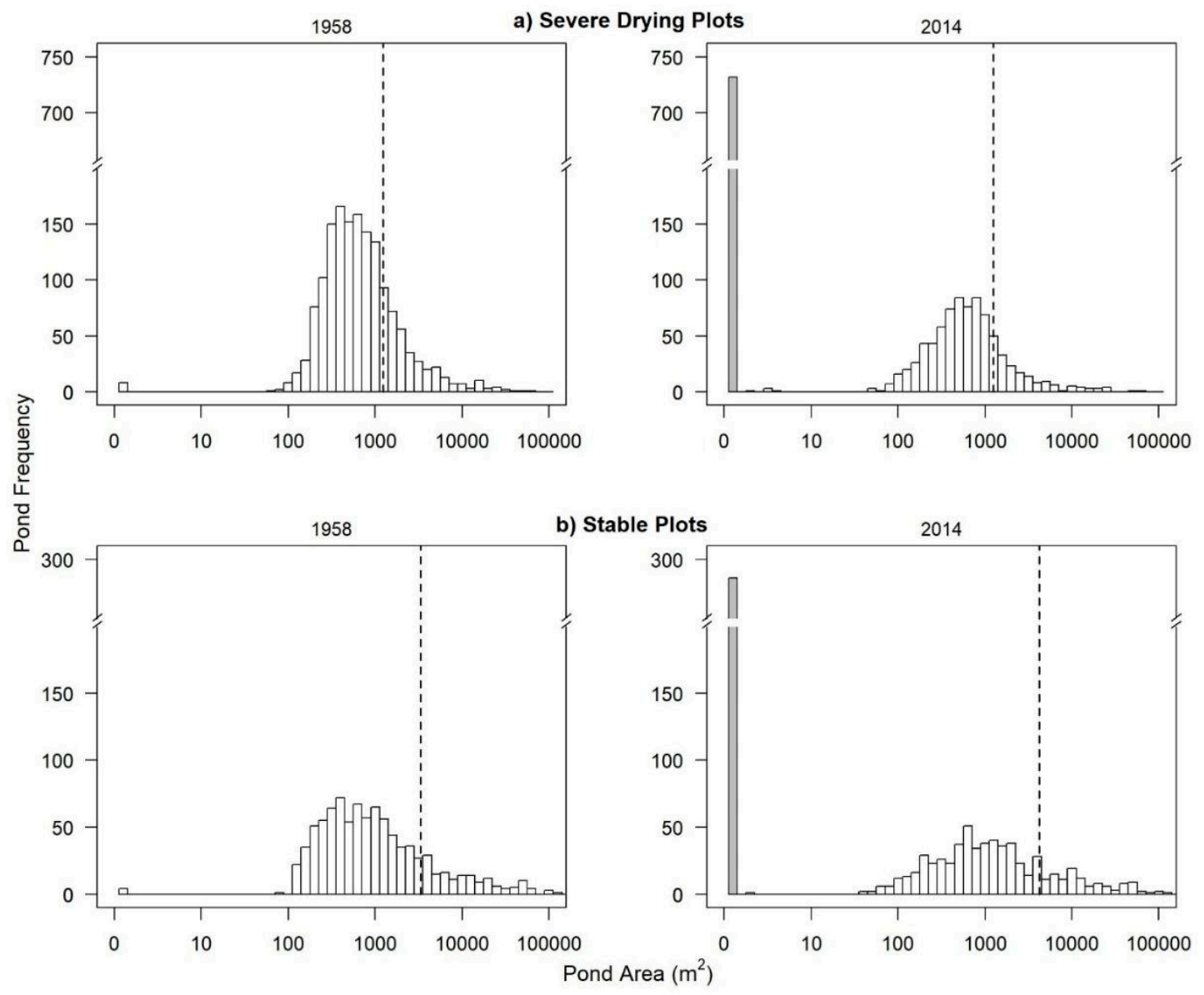

Figure 4. Size distributions of waterbodies mapped using aerial imagery, split by plot type and year. The dashed black lines show the average waterbody size within that year and plot, excluding waterbodies with a size of $0 \mathrm{~m}^{2}$. The grey bars in 2014 show the number of waterbodies that experienced complete drainage. 
Table 2. Observed and expected size class distributions of waterbodies in severe drying and stable plots, based on the chi-square analysis. Bold numbers indicate that the number of observed waterbodies exceeds the number of expected waterbodies. Numbers with an asterisk indicate a significant difference from the expected value, using a Bonferroni correction $(p<0.0063)$.

\begin{tabular}{ccccc}
\hline & \multicolumn{2}{c}{ Severe Drying } & \multicolumn{2}{c}{ Stable } \\
\cline { 2 - 5 } & Observed & Expected & Observed & Expected \\
\hline $50-450 \mathrm{~m}^{2}$ & $\mathbf{6 2 5}$ & 597 & 324 & 352 \\
$450-900 \mathrm{~m}^{2}$ & $\mathbf{4 5 5 *}$ & 402 & $184 *$ & 237 \\
$900-1800 \mathrm{~m}^{2}$ & 249 & 255 & $\mathbf{1 5 6}$ & 150 \\
$1800-3600 \mathrm{~m}^{2}$ & $100^{*}$ & 121 & $\mathbf{9 3}$ & 72 \\
$3600-7200 \mathrm{~m}^{2}$ & 53 & 64 & $\mathbf{4 9}$ & 38 \\
$7200-14,400 \mathrm{~m}^{2}$ & $15^{*}$ & 35 & $\mathbf{4 1}$ & 21 \\
$14,400-28,800 \mathrm{~m}^{2}$ & $14^{*}$ & 23 & $\mathbf{2 2}$ & 13 \\
$28,800-120,000 \mathrm{~m}^{2}$ & $4^{*}$ & 18 & $\mathbf{2 5}^{*}$ & 11 \\
\hline Column totals & 1515 & 1515 & 894 & 894 \\
\hline
\end{tabular}

Across all plots, $47.8 \%$ of the total surface water loss occurred in waterbodies smaller than $1800 \mathrm{~m}^{2}$, despite the fact that these waterbodies only accounted for $20.5 \%$ of the total surface area in 1958 (Table 3). Smaller waterbodies lost a higher proportion of their total area, compared to larger waterbodies (Figure 5). The smallest size class $\left(50-450 \mathrm{~m}^{2}\right)$ lost $90.6 \%$ of the total area, compared to the $5 \%$ lost by the largest size class $\left(28,800-120,000 \mathrm{~m}^{2}\right)$.

Table 3. Summary statistics including the total number, area, change in area, and proportion of change for waterbodies in different size classes.

\begin{tabular}{ccccccccc}
\hline Waterbody Size in $\left.\mathbf{1 9 5 8} \mathbf{( m}^{\mathbf{2}}\right)$ & $\mathbf{5 0 - 4 5 0}$ & $\mathbf{4 5 0 - 9 0 0}$ & $\mathbf{9 0 0 - 1 8 0 0}$ & $\mathbf{1 8 0 0 - 3 6 0 0}$ & $\mathbf{3 6 0 0 - 7 2 0 0}$ & $\mathbf{7 2 0 0 - 1 4 , 4 0 0}$ & $\mathbf{1 4 , 4 0 0 - 2 8 , 8 0 0}$ & $\mathbf{2 8 , 8 0 0 - 1 2 0 , 0 0 0}$ \\
\hline Count & 949 & 639 & 405 & 193 & 102 & 56 & 36 & 29 \\
Total area $\left(\mathbf{m}^{\mathbf{2}}\right)$ & 213,525 & 431,325 & 546,750 & 521,100 & 550,800 & 604,800 & 777,600 & $2,157,600$ \\
Change in total area $\left(\mathbf{m}^{\mathbf{2}}\right)$ & $-193,437$ & $-212,536$ & $-204,329$ & $-153,752$ & $-151,374$ & $-119,682$ & $-142,308$ & $-107,254$ \\
Proportion of total area lost & $90.59 \%$ & $49.28 \%$ & $37.37 \%$ & $29.51 \%$ & $27.48 \%$ & $19.79 \%$ & $18.30 \%$ & $4.97 \%$ \\
\hline
\end{tabular}
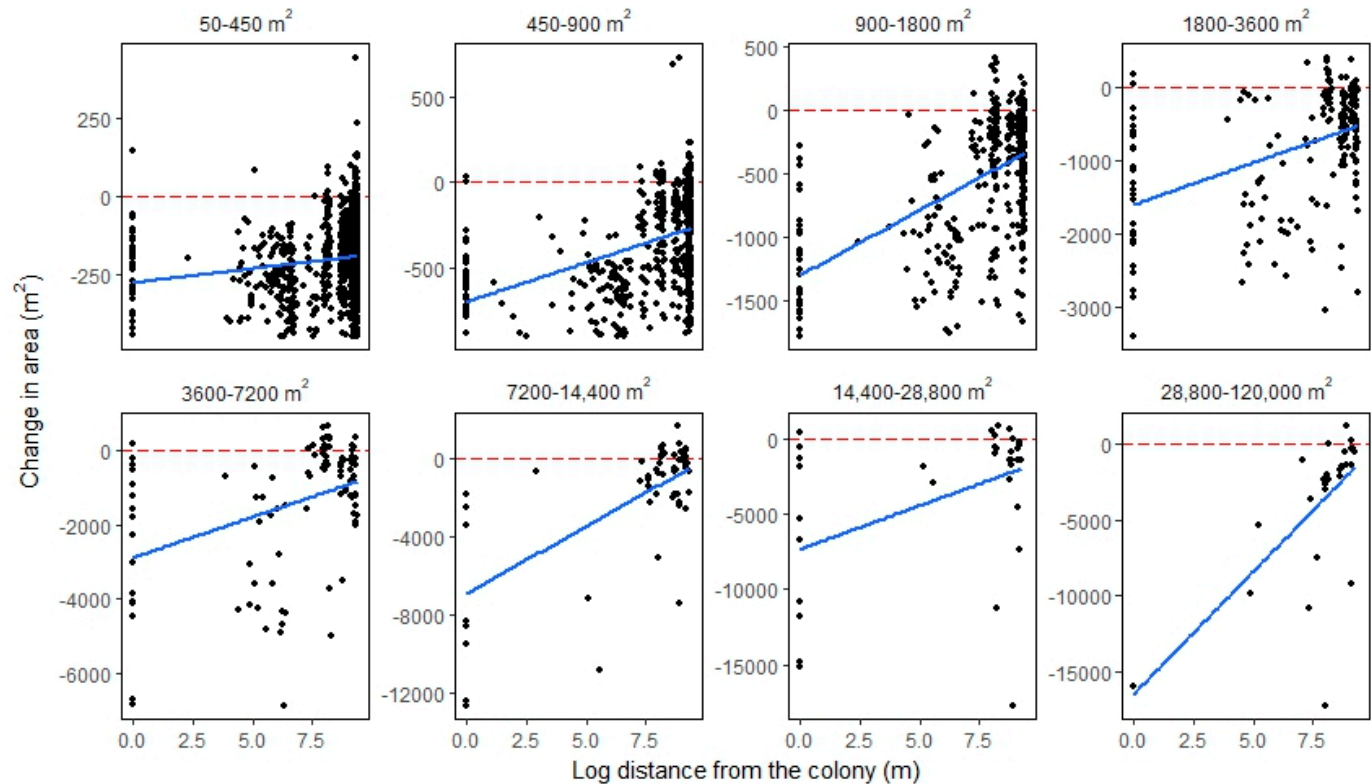

Figure 5. Visualization of the interaction effect (distance from the colony and waterbody size) in the best model (Table 4). Data were divided based on the waterbody size classes indicated above each panel. Each point represents the change in area of a single waterbody. The blue lines show model predictions for waterbody area change within that size class. The dotted red reference lines show no change in waterbody area. 
Table 4. Candidate models for change in waterbody area, with goodness-of-fit metrics. The table is ordered by the model fit, and the best model is shown in bold.

\begin{tabular}{|c|c|c|c|c|c|c|}
\hline $\begin{array}{c}\text { Model } \\
\text { Number }\end{array}$ & Explanatory Variables & $\mathbf{R}^{2}$ & $\mathrm{AICc}$ & $\Delta \mathrm{AICc}$ & $\begin{array}{c}\text { AICc } \\
\text { Weight }\end{array}$ & Rank \\
\hline 7 & $\begin{array}{l}\log (\text { Colony Distance })+\text { Pond Size }+ \\
\log (\text { Colony Distance }) \times \text { Pond Size }\end{array}$ & 0.429 & 39960.4 & 0 & 1.0 & 1 \\
\hline 6 & $\log ($ Colony Distance $)+$ Pond Size & 0.291 & 40482.6 & 522.2 & $4.0 \times 10^{-114}$ & 2 \\
\hline 4 & 2015 TCG + Pond Size + 2015 TCG $\times$ Pond Size & 0.276 & 40532.4 & 572.0 & $6.2 \times 10^{-125}$ & 3 \\
\hline 3 & 2015 TCG + Pond Size & 0.220 & 40710.3 & 749.9 & $1.4 \times 10^{-163}$ & 4 \\
\hline 1 & Pond Size & 0.211 & 40739.5 & 779.1 & $6.5 \times 10^{-170}$ & 5 \\
\hline 9 & Flow Accumulation + Pond Size & 0.210 & 40741.0 & 780.6 & $3.1 \times 10^{-170}$ & 6 \\
\hline 10 & $\begin{array}{c}\text { Flow Accumulation }+ \text { Pond Size }+ \text { Flow } \\
\text { Accumulation } \times \text { Pond Size }\end{array}$ & 0.210 & 40742.5 & 782.1 & $1.4 \times 10^{-170}$ & 7 \\
\hline 5 & $\log ($ Colony Distance $)$ & 0.0995 & 41056.4 & 1096.0 & $9.8 \times 10^{-239}$ & 8 \\
\hline 2 & 2015 TCG & 0.00926 & 41286.4 & 1326.0 & $1.1 \times 10^{-288}$ & 9 \\
\hline 8 & Flow Accumulation & 0.00264 & 41302.5 & 1342.1 & $3.6 \times 10^{-292}$ & 10 \\
\hline
\end{tabular}

In stable and severe drying plots, there was an increase in the mean size of waterbodies present in 2014 (Figure 4), which is indicative of a disproportionate loss of small waterbodies. The change in mean waterbody size between 1958-2014 was considerably smaller in severe drying plots $\left(\Delta 9.4 \mathrm{~m}^{2}\right)$, compared to stable plots $\left(\Delta 876.9 \mathrm{~m}^{2}\right)$, which showed a more balanced loss of waterbodies of varying sizes.

\subsubsection{Model Selection}

The model selection procedure showed that large reductions in waterbody area were most strongly associated with waterbody size and proximity to the nesting colony. The best model included an interaction between the distance from the colony and pond size measurements (Table 4). Waterbody area losses were larger near the colony regardless of waterbody size, but the impact of the colony was most obvious in larger waterbodies. This was evidenced by an increase in the slope of the relationship between the distance from the colony and area loss in larger waterbodies (Figure 5).

\subsubsection{Categorical Proportional Area Loss}

All waterbody size classes, except the largest $\left(>28,800 \mathrm{~m}^{2}\right)$, had significantly greater proportional area loss $(p<0.05)$ within $1 \mathrm{~km}$ of the nesting colony, compared to waterbodies between $1-5 \mathrm{~km}$ and further than $5 \mathrm{~km}$ from the nesting colony (Figure 6). At distances greater than $1 \mathrm{~km}$ from the nesting colony, waterbodies showed similar proportional changes in all size classes. Regardless of distance from the colony, the smallest waterbody size class had the largest proportional area loss at $95.3 \%+/-9.2$ for $0-1 \mathrm{~km}$ from the nesting colony, $76.3 \%+/-11.1$ for $1-5 \mathrm{~km}$, and $74.4 \%+/-7.8$ for greater than $5 \mathrm{~km}$.

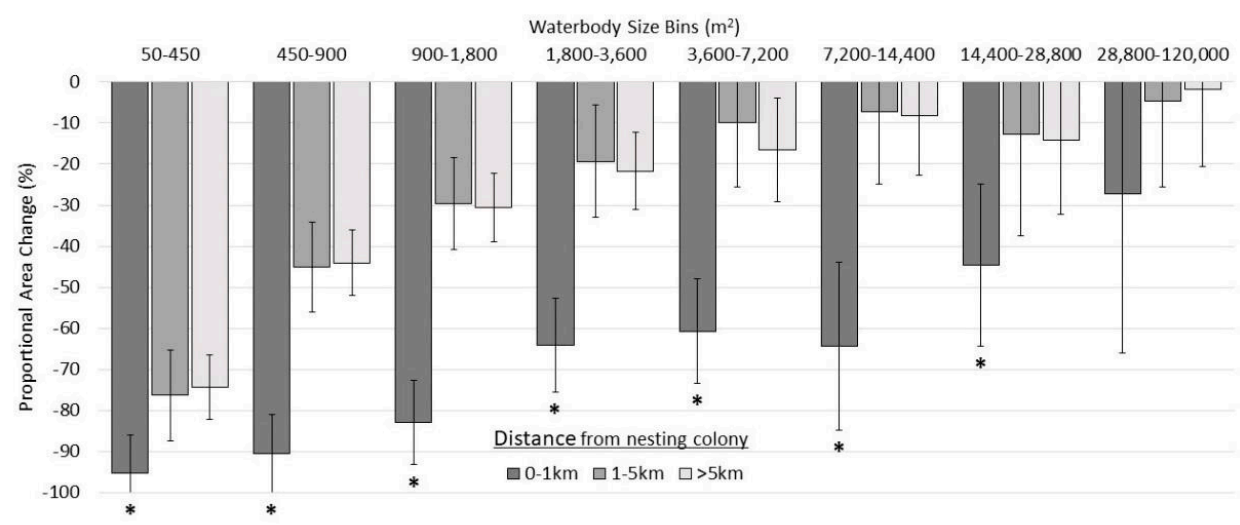

Figure 6. Bar plots showing the proportional area change by distance from the nesting colony and waterbody size intervals. The error bars represent $95 \%$ confidence intervals. Asterisks are present when the $0-1 \mathrm{~km}$ distance group is significantly different from the other distance groups based on the least-squares means estimates. 


\subsection{Field Surveys}

\subsubsection{Pond Basin Transect Intersections}

Field surveys showed evidence of widespread drying, as all site types intersected former pond basins to some extent. Colony sites had the highest proportion of former pond basins (75.76\%), then drying sites (31.82\%), and then control sites (2.05\%) (Figure 7). Regardless of site type, former pond basins intersected transect lines exclusively within pixels that experienced negative SWF trends.
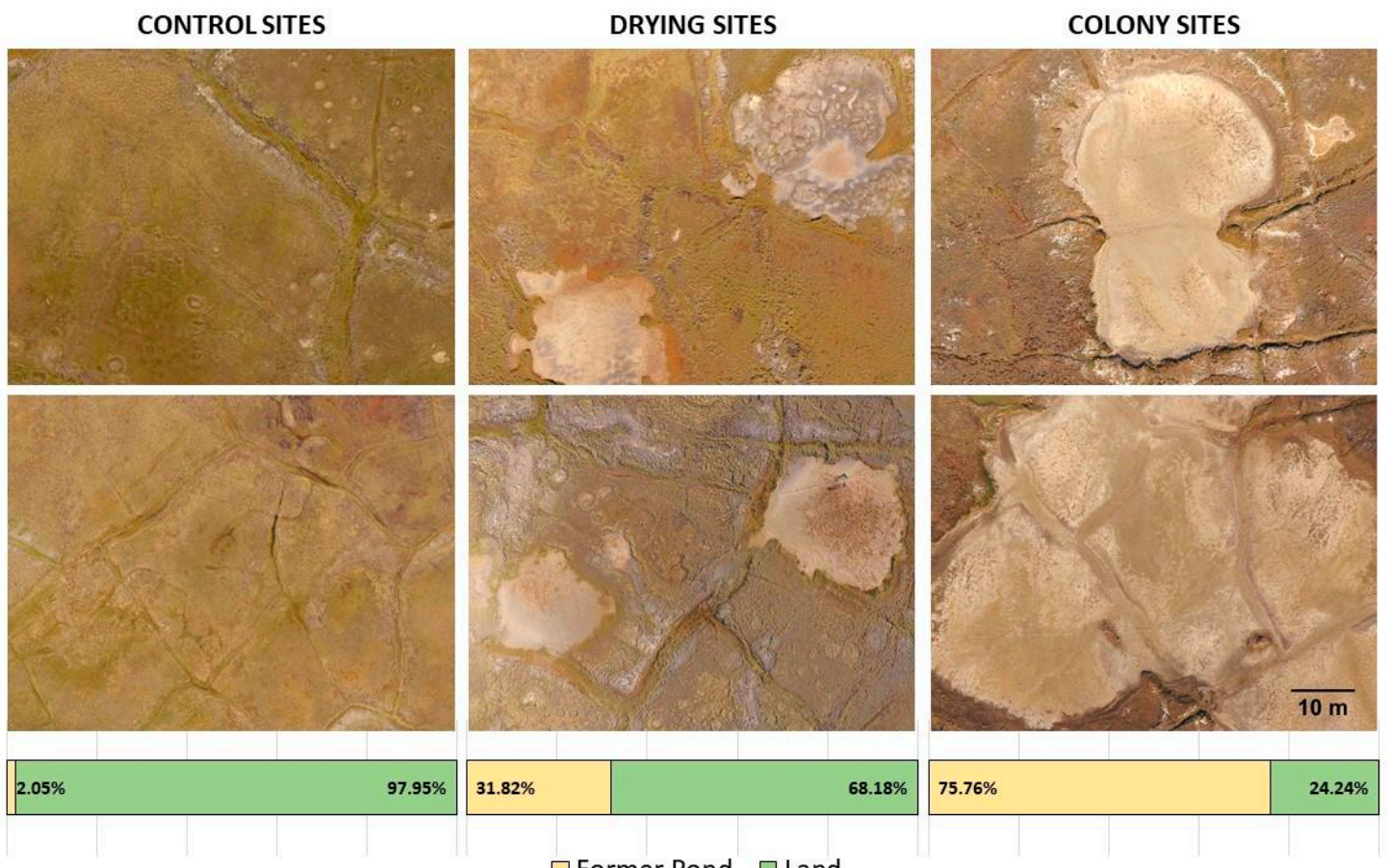

$\square$ Former Pond $\quad \square$ Land

Figure 7. Aerial photographs captured using an unmanned aerial vehicle (UAV) during July 2017 field surveys. The bars below the images show the proportion of field transects classified as former pond basins and regular land.

\subsubsection{Biotic and Abiotic Site Differences}

Soils were significantly drier at colony sites $(p<0.05)$ compared to the control and drying site types, which were not significantly different from each other (Figure 8). Mean soil volumetric water content was three times lower at colony sites $(24.6 \%+/-30.4 \%)$, compared to drying $(78.4 \%+/-24.6 \%)$ and control sites $(72.2 \%+/-15.8 \%)$. Thaw depth was not significantly different among site types (Figure S2). Vegetation cover was also significantly lower at the colony sites $(p<0.01)$ (Figure 8), where groundcover was dominated by exposed peat. Mean vascular plant cover was 10-15 times lower at colony sites $(4.1 \%+/-23.6 \%)$, compared to drying $(43.8 \%+/-18.2 \%)$ and control sites $(59.5 \%+/-10.9 \%)$. Goose grubbing was not significantly different among site types (Figure S2). 


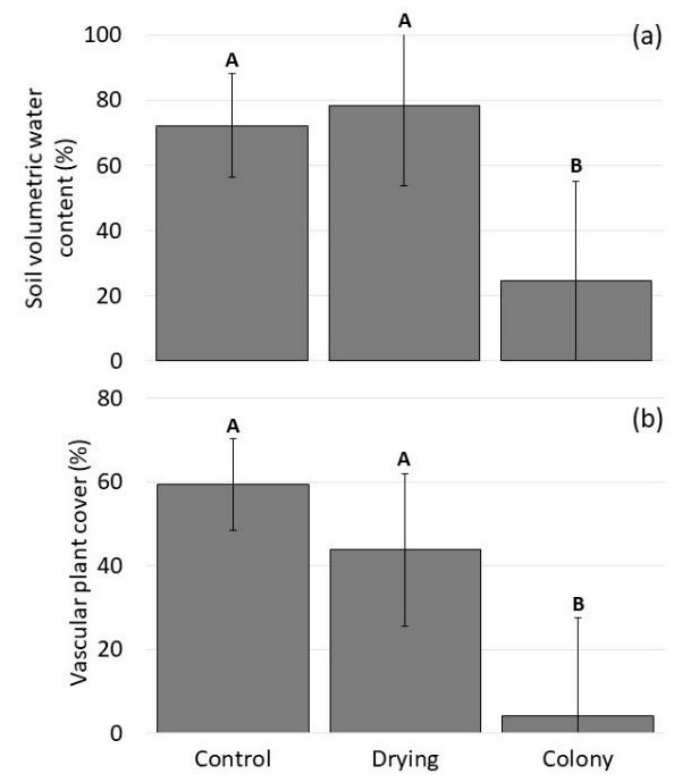

Figure 8. Least-squares means estimates of (a) soil volumetric water content and (b) vegetation cover from the linear mixed effects models. Error bars represent $95 \%$ confidence intervals and bars with different letters are significantly different.

\section{Discussion}

The results of our analyses confirm our hypothesis that the number and size of waterbodies in the pond complexes of western Banks Island are decreasing. This observation differs from most surface water studies in the low Arctic [17,19], which have reported increases in surface water. In the pond complexes of western Banks Island, only a small portion of existing waterbodies expanded and few new waterbodies emerged. This indicates that surface water responses to climate change in high Arctic regions are distinct and require additional research, as the high Arctic is one of Canada's largest ecozones, covering about 15\% of the country. Estimates of change in surface water based on the SWF analysis and manual aerial imagery digitization span different time periods, but results from both sources of information showed similar patterns of substantial surface water loss.

\subsection{Smaller Waterbodies Are More Vulnerable}

Our observation that small waterbodies are being disproportionately affected is aligned with our second hypothesis and suggests that climate is the main driver of drying in the study area. Almost half of the loss in surface water occurred in small waterbodies $\left(50-1800 \mathrm{~m}^{2}\right)$, despite only making up $20.5 \%$ of the total surface water in 1958 . There are several climate-driven processes that may be contributing to the loss of surface water on Banks Island. Warming summer temperatures and extended ice-free seasons increase annual evaporative losses and can lead to the complete desiccation of waterbodies $[15,62]$. The effects of this would be most evident in small and shallow waterbodies because of their high surface area to volume ratios $[15,20,21]$. Declines in terrestrial water storage in large river basins across the Arctic have also been linked to increases in evapotranspiration [64]. Warmer and longer summers would also reduce summer snowpack, which might be sustaining wet areas with meltwater throughout the ice-free season [26,28,65]. Most of the summer snowpack observed in the 1958 aerial photographs was not visible in the 2014 aerial imagery, despite having acquisition dates only five days apart. Warming air and ground temperatures can also increase thaw depth and groundwater storage capacities, which might lower the water table [28]. This would reduce hydrological connectivity [28] and could potentially desiccate shallow waterbodies perched above the lowered water table. Degradation of low-centered polygonal terrain, from increasing ground temperatures, would also result in a large loss of small waterbodies [66]. As low-centered polygons 
degrade into high-centered polygons, their capacity to hold water decreases. Our data suggests this is not occurring because it would also result in an increase in waterbodies in the trough areas of the polygons [66], which we did not observe. Furthermore, areas visited in the field, which experienced concentrated losses of small waterbodies, have remained as low-centered polygonal terrain. Further investigation is needed to evaluate the potential contributions of these processes and to understand how similar terrain types in other regions of the Arctic are being impacted. The knowledge of hunters and land-users can also provide significant insight into these processes [67-69].

Our finding that small ponds are the most vulnerable to change highlights the importance of using fine-scale data or sub-pixel/spectral un-mixing techniques for surface water change detection in areas with small waterbody size distributions. It is important to use data at appropriate scales or remote sensing techniques that are matched with the biophysical variation in the area of interest. In our study area, most waterbodies were smaller than $900 \mathrm{~m}^{2}$, the size of the Landsat pixel footprint. Previous broad-scale analyses, not considering sub-pixel information [70], were only sensitive to changes impacting the majority of a pixel and therefore did not detect the magnitude of change we observed.

\subsection{Intensified Drying in the Nesting Colony}

Our results also confirm our hypothesis that surface water changes are following different trajectories in the nesting colony area and indicate that the intensive occupation of lesser snow geese may be reducing the resilience of waterbodies to climate warming by facilitating drying or draining processes. Reductions in waterbody area were larger and more consistent closer to the nesting colony, regardless of original waterbody size. Colony sites were shown to have reduced vegetation cover and soil moisture, which are common impacts of overgrazing in expanding snow goose nesting colonies [34,35]. Vegetation provides a strong insulating layer that stabilizes near-surface ground temperatures and increases soil moisture retention [34,37]. In other regions, reductions in the vegetation layer associated with intense goose activity have been found to increase evaporation in soils [34], which may reduce subsurface hydrological connectivity. Waterbodies isolated from subsurface inputs are also more vulnerable to desiccation over the ice-free season $[26,27,62]$.

Trampling by lesser snow geese, which can create depressions and terraces [36], likely contributes to reduced vegetation cover to increase the risk of lateral drainage through accelerated degradation of ice-wedge polygons. Ice-wedge polygons are one of the most common forms of ground ice in the Arctic [71,72] and were ubiquitous at our field sites. These features have been suggested to be more vulnerable to degradation in higher latitude areas because wedge ice is located closer to the ground surface and is less insulated from changing air temperatures $[29,30]$.

Since lesser snow goose breeding areas are synonymous with wet Arctic habitats, a better understanding of the impacts of these animals on permafrost and surface water dynamics is important. Similar patterns of surface water loss can be seen in the lowland areas of Southampton Island, Nunavut [70], which hosts the third largest lesser snow goose population in the Canadian Arctic [35]. As populations continue to expand, impacts on freshwater systems in the Canadian Arctic are likely to intensify. Further research on snow goose habitat impacts to permafrost and surface water dynamics are necessary, as this topic is largely unstudied to date.

\subsection{Implications}

Drying of high Arctic wetlands will impact lesser snow geese and other herbivore populations, as these areas provide important breeding habitat in largely arid polar deserts [35]. A recent study projected $30-80 \%$ reductions in lake extent within the areas of five Alaskan National Wildlife Refuges over the next 50 years, and anticipated that these areas would not persist as important waterfowl production areas if rates of change continue [23]. Changes in the extent of surface water can also affect permafrost thaw [12-14] and increase methane and carbon dioxide emissions with shoreline 
expansion [12,73]. Understanding surface water changes in high Arctic environments is therefore critical for making accurate evaluations of greenhouse gas emissions across the Arctic.

\section{Conclusions}

Based on the data analyzed here, we draw the following conclusions:

- The pond complexes on western Banks Island are drying.

- Wetland drying is being caused by warming climate, but is exacerbated in areas with intensive snow goose habitat use.

- Future studies should explore the mechanisms causing pond desiccation, the impacts of snow geese on these processes, and the impacts of drying on vegetation and permafrost conditions.

- Remote sensing studies must use data and methods that consider the biophysical variation in the area of interest to adequately assess environmental changes.

Supplementary Materials: The following are available online at http:/ / www.mdpi.com/2072-4292/10/12/1892/ s1, Figure S1: Study methods flow diagram, Figure S2: Linear mixed effects model outputs for thaw depth and goose grubbing.

Author Contributions: Conceptualization-T.K.F.C. and T.C.L.; methodology-T.K.F.C., T.C.L., and R.H.F.; software-T.K.F.C. and R.H.F.; validation-T.K.F.C., T.C.L., and R.H.F.; formal analysis-T.K.F.C.; investigation-T.K.F.C., T.C.L., and R.H.F.; resources-R.H.F. and T.C.L.; data curation-T.C.L. and R.H.F.; writing-original draft preparation, T.K.F.C.; writing-review and editing, T.C.L. and R.H.F.; visualization-T.K.F.C.; supervision-T.C.L.; project administration-T.C.L.; funding acquisition-T.C.L.

Funding: This research was funded by: The Polar Continental Shelf Program; the Natural Sciences and Engineering Research Council of Canada; ArcticNet; the Northern Scientific Training Program; the Canadian Space Agency Government Related Initiatives Program (GRIP); and the University of Victoria.

Acknowledgments: This work was made possible by the Aurora Research Institute-Western Arctic Research Centre, the Canadian Wildlife Service-Yellowknife, and the Sachs Harbour Hunters and Trappers Committee. We thank Marie Fast, Megan Ross, Danica Hogan, Eric Reed, and Cindy Wood from the Canadian Wildlife Service, as well as Trevor Lucas, from the Sachs Harbour Hunters and Trappers Committee, for their critical in-field and logistical support. We also thank Ian Olthof and Hana Travers-Smith for their assistance with the collection and processing of remote sensing data.

Conflicts of Interest: The authors declare no conflict of interest. 


\section{Appendix A}

\begin{tabular}{|l|l|} 
Change in surface water $\left(\mathbf{m}^{\wedge} \mathbf{2}\right)$ & $\square$ \\
\hline$-900--600$ & $-0.99-1$ \\
$-599--300$ & $2-300$ \\
$-299--1$ & $301-600$ \\
\hline & $601-900$
\end{tabular}
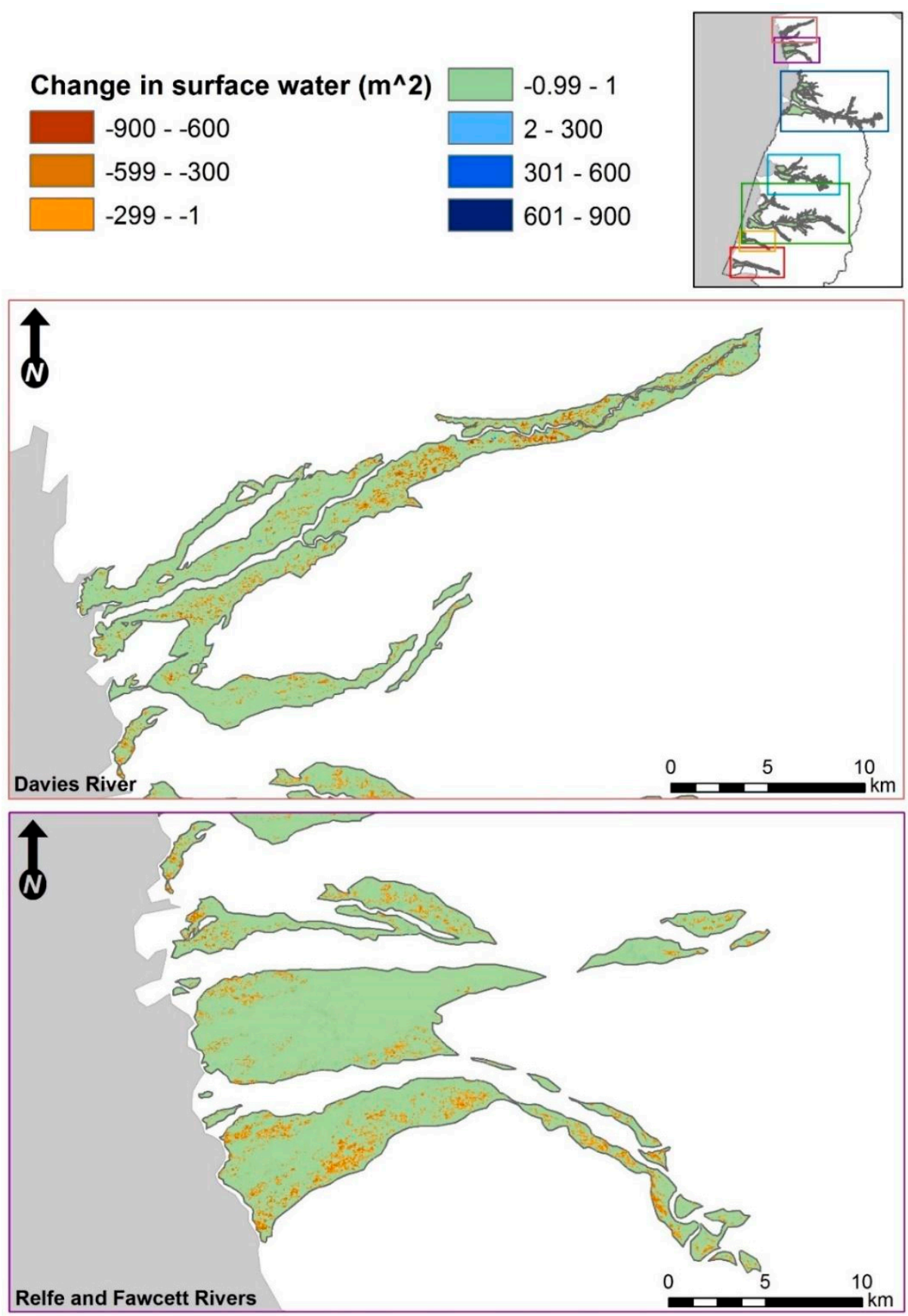

Figure A1. Sub-pixel water fraction trend surfaces of the Davies, Relfe, and Fawcett river valleys of western Banks Island, between 1985-2015. 

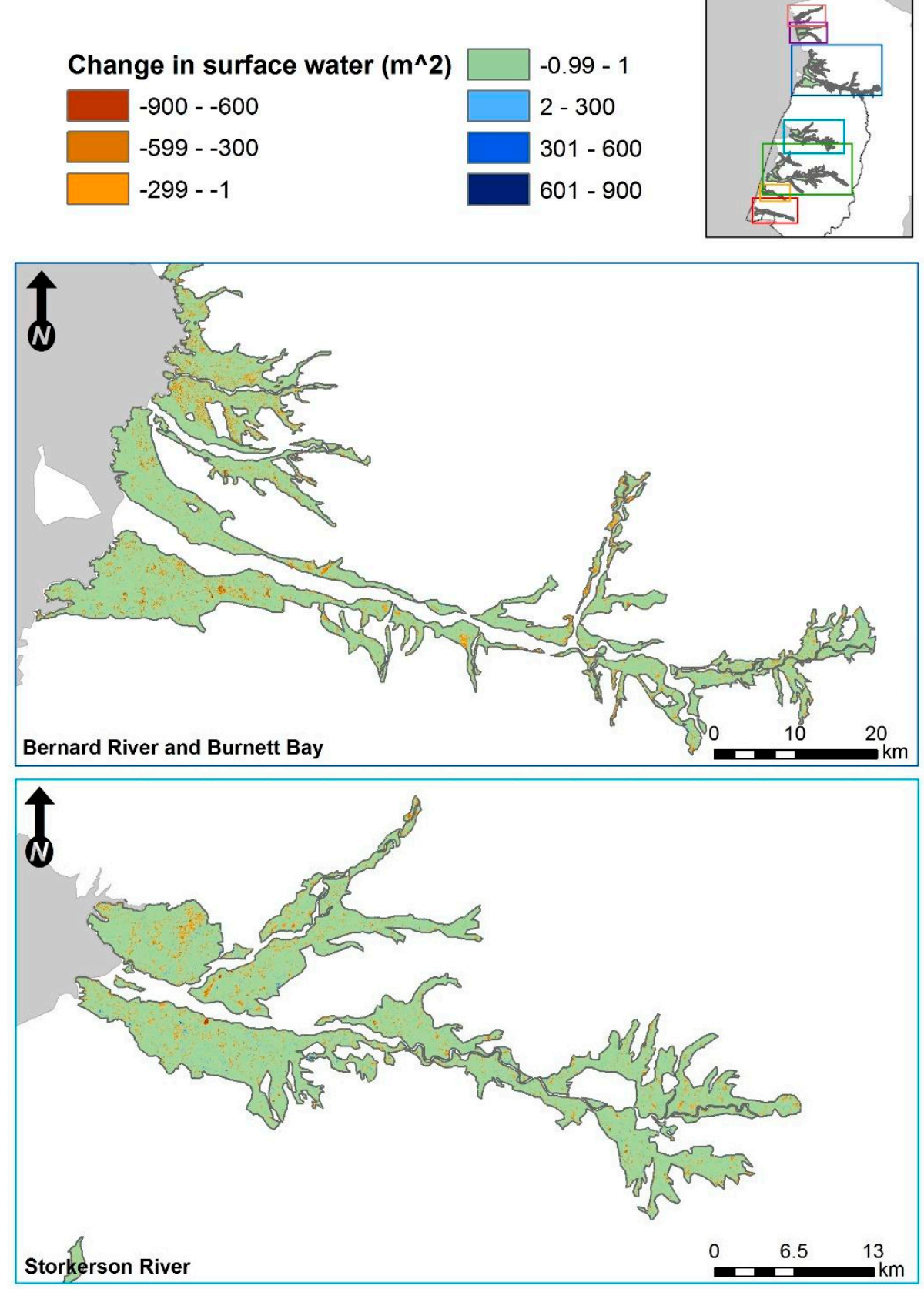

Figure A2. Sub-pixel water fraction trend surfaces of the Burnett Bay area, and the Bernard and Storkerson river valleys of western Banks Island, between 1985-2015. 

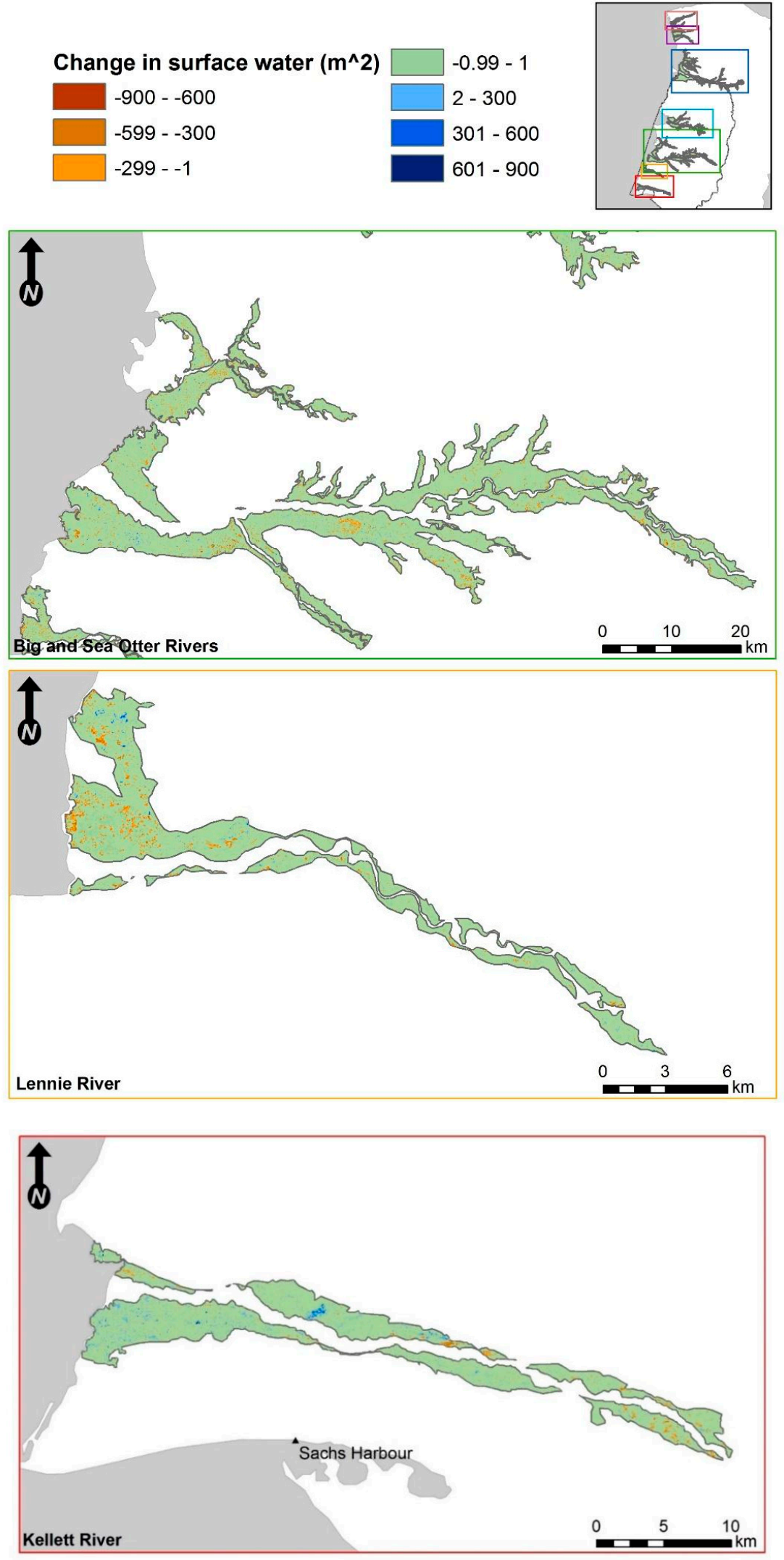

Figure A3. Sub-pixel water fraction trend surfaces of the Sea Otter, Big, Lennie, and Kellett river valleys of western Banks Island, between 1985-2015. 


\section{References}

1. AMAP (Arctic Monitoring and Assessment Programme). Arctic Climate Issues 2011: Changes in Arctic Snow, WATER, ice and Permafrost; SWIPA 2011 Overview Report; AMAP: Oslo, Norway, 2012; p. 97.

2. Pithan, F.; Mauritsen, T. Arctic amplification dominated by temperature feedbacks in contemporary climate models. Nat. Geosci. 2014, 7, 181-184. [CrossRef]

3. Lantz, T.C.; Turner, K.W. Changes in lake area in response to thermokarst processes and climate in Old Crow Flats, Yukon. J. Geophys. Res. Biogeosci. 2015, 120, 513-524. [CrossRef]

4. Kaplan, J.O.; New, M. Arctic climate change with a $2{ }^{\circ} \mathrm{C}$ global warming: Timing, climate patterns and vegetation change. Clim. Chang. 2006, 79, 213-241. [CrossRef]

5. Bintanja, R.; Andry, O. Towards a rain-dominated Arctic. Nat. Clim. Chang. 2017, 7, 263-268. [CrossRef]

6. Yoshikawa, K.; Hinzman, L.D. Shrinking thermokarst ponds and groundwater dynamics in discontinuous permafrost near Council Alaska. Permafr. Periglac. Process. 2003, 14, 151-160. [CrossRef]

7. Nitze, I.; Grosse, G.; Jones, B.M.; Arp, C.D.; Ulrich, M.; Fedorov, A.; Veremeeva, A. Landsat-based trend analysis of lake dynamics across northern permafrost regions. Remote Sens. 2017, 9, 640. [CrossRef]

8. Wolfe, B.B.; Light, E.M.; Macrae, M.L.; Hall, R.I.; Eichel, K.; Jasechko, S.; White, J.; Fishback, L.; Edwards, T.W.D. Divergent hydrological responses to 20th century climate change in shallow tundra ponds, western Hudson Bay Lowlands. Geophys. Res. Lett. 2011, 38, 1-6. [CrossRef]

9. Negandhi, K.; Laurion, I.; Whiticar, M.J.; Galand, P.E.; Xu, X.; Lovejoy, C. Small thaw ponds: An unaccounted source of methane in the Canadian high Arctic. PLoS ONE 2013, 8, e78204. [CrossRef] [PubMed]

10. Becker, M.S.; Davies, T.J.; Pollard, W.H. Ground ice melt in the high Arctic leads to greater ecological heterogeneity. J. Ecol. 2016, 104, 114-124. [CrossRef]

11. Slattery, S.M.; Alisauskas, R.T. Distribution and habitat use of Ross' and lesser snow geese during late brood rearing. J. Wildl. Manag. 2007, 71, 2230-2237. [CrossRef]

12. Anthony, K.W.; Daanen, R.; Anthony, P.; Schneider von Deimling, T.; Ping, C.-L.; Chanton, J.P.; Grosse, G. Methane emissions proportional to permafrost carbon thawed in Arctic lakes since the 1950s. Nat. Geosci. 2016, 9, 679-685. [CrossRef]

13. White, D.; Hinzman, L.; Alessa, L.; Cassano, J.; Chambers, M.; Falkner, K.; Francis, J.; Gutowski, W.J., Jr.; Holland, M.; Holmes, R.M.; et al. The arctic freshwater system: Changes and impacts. J. Geophys. Res. 2007, 112, G04S54. [CrossRef]

14. Raymond, P.A.; Hartmann, J.; Lauerwald, R.; Sobek, S.; McDonald, C.; Hoover, M.; Butman, D.; Striegl, R.; Mayorga, E.; Humborg, C.; et al. Global carbon dioxide emissions from inland waters. Nature 2013, 503, 355-387. [CrossRef] [PubMed]

15. Smol, J.P.; Douglas, S.V. Crossing the final ecological threshold in high Arctic ponds. PNAS 2007, 104, 12395-12397. [CrossRef] [PubMed]

16. Plug, L.J.; Walls, C.; Scott, B.M. Tundra lake changes from 1978 to 2001 on the Tuktoyaktuk Peninsula, western Canadian Arctic. Geophys. Res. Lett. 2008, 35, L03502. [CrossRef]

17. Smith, L.C.; Sheng, Y.; MacDonald, G.M.; Hinzman, L.D. Disappearing Arctic lakes. Science 2005, $308,1429$. [CrossRef] [PubMed]

18. Jones, B.M.; Grosse, G.; Arp, C.D.; Jones, M.C.; Anthony, K.M.W.; Romanovsky, V.E. Modern thermokarst lake dynamics in the continuous permafrost zone, northern Seward Peninsula, Alaska. J. Geophys. Res. 2011, 116, G00M03. [CrossRef]

19. Olthof, I.; Fraser, R.H.; Schmitt, C. Landsat-based mapping of thermokarst lake dynamics on the Tuktoyaktuk coastal plain: Northwest Territories, Canada since 1985. Remote Sens. Environ. 2015, 168, 194-204. [CrossRef]

20. Arp, C.D.; Jones, B.M.; Urban, F.E.; Grosse, G. Hydrogeomorphic processes of thermokarst lakes with grounded-ice and floating-ice regimes on the Arctic coastal plain, Alaska. Hydrol. Process. 2011, 25, 2422-2438. [CrossRef]

21. Marsh, P.; Bigras, S.C. Evaporation from Mackenzie Delta lakes, N.W.T., Canada. Arct. Alp. Res. 1988, 20, 220-229. [CrossRef]

22. Turner, K.W.; Wolfe, B.B.; Edwards, T.E.; Lantz, T.C.; Hall, R.I.; La Rocque, G. Controls on water balance of shallow thermokarst lakes and their relations with catchment characteristics: A multi-year, landscape-scale assessment based on water isotope tracers and remote sensing in Old Crow Flats, Yukon (Canada). Glob. Chang. Boil. 2014, 20, 1585-1603. [CrossRef] 
23. Roach, J.K.; Griffith, B.; Verbyla, D. Landscape influences on climate-related lake shrinkage at high latitudes. Glob. Chang. Boil. 2013, 19, 2276-2284. [CrossRef] [PubMed]

24. Carroll, M.L.; Townshend, J.R.G.; DiMiceli, C.M.; Loboda, T.; Sohlberg, R.A. Shrinking lakes of the Arctic: Spatial relationships and trajectory of change. Geophys. Res. Lett. 2011, 38, 1-5. [CrossRef]

25. Riordan, B.; Verbyla, D.; McGuire, A.D. Shrinking ponds in subarctic Alaska based on 1950-2002 remotely sensed images. J. Geophys. Res. 2006, 111, G04002. [CrossRef]

26. Woo, M.-K.; Young, K.L. High Arctic wetlands: Their occurrence, hydrological characteristics and sustainability. J. Hydrol. 2006, 320, 432-450. [CrossRef]

27. Abnizova, A.; Young, K.L. Sustainability of high Arctic ponds in a polar desert environment. Arctic 2010, 63, 67-84. [CrossRef]

28. Woo, M.-K.; Young, K.L.; Brown, L. High Arctic patchy wetlands: Hydrological variability and their sustainability. Phys. Geogr. 2006, 27, 297-307. [CrossRef]

29. Steedman, A.E.; Lantz, T.C.; Kokelj, S.V. Spatio-temporal variation in high-centre polygons and ice-wedge melt ponds, Tuktoyaktuk Coastlands, Northwest Territories. Permafr. Periglac. Process. 2017, 28, 66-78. [CrossRef]

30. Fraser, R.H.; Kokelj, S.V.; Lantz, T.C.; McFarlane-Winchester, M.; Olthof, I.; Lacelle, D. Climate sensitivity of high Arctic permafrost terrain demonstrated by widespread ice-wedge thermokarst on Banks Island. Remote Sens. 2018, 10, 954. [CrossRef]

31. Hines, J.E.; Latour, P.B.; Squires-Taylor, C.; Moore, S. The Effects on Lowland Habitat in the Banks Island Bird Sanctuary Number 1, Northwest Territories, by the Growing Colony of Lesser Snow Geese (Chen caerulescens caerulescens); Environment Canada Occasional Paper 118; Environment Canada, Canadian Wildlife Service: Edmonton, AB, Canada, 2010; pp. 8-26.

32. Batt, B.D.J. Arctic Ecosystems in Peril: Report of the Arctic Goose Habitat Working Group; Arctic Goose Joint Venture Special Publication; U.S. Fish and Wildlife Service: Washington, DC, USA; Canadian Wildlife Service: Ottawa, ON, Canada, 1997; pp. 1-12. ISBN 0961727934.

33. Kotanen, P.M.; Jefferies, R.L. Long-term destruction of sub-arctic wetland vegetation by lesser snow geese. Ecoscience 1997, 4, 179-182. [CrossRef]

34. Srivastava, D.S.; Jefferies, R.L. A positive feedback: Herbivory, plant growth, salinity, and the desertification of an Arctic salt-marsh. J. Ecol. 1996, 84, 31-42. [CrossRef]

35. Calvert, A.M. Interactions between Light Geese and Northern Flora and Fauna: Synthesis and Assessment of Potential Impacts; Unpublished Report; Environment Canada: Ottawa, ON, Canada, 2015; pp. 1-37.

36. Jefferies, R.L.; Jensen, A.; Abraham, K.F. Vegetational development and the effect of geese on vegetation at La Perouse Bay, Manitoba. Can. J. B 1979, 57, 1439-1450. [CrossRef]

37. Iacobelli, A.; Jefferies, R.L. Inverse salinity gradients in coastal marshes and the death of stands of Salix: The effects of grubbing by geese. J. Ecol. 1991, 79, 61-73. [CrossRef]

38. Park, J.S. A race against time: Habitat alteration by snow geese prunes the seasonal sequence of mosquito emergence in a subarctic brackish landscape. Polar Biol. 2017, 40, 553-561. [CrossRef]

39. Mudryk, L.R.; Derksen, C.; Howell, S.; Laliberte, F.; Thackeray, C.; Sospedra-Alfonso, R.; Vionnet, V.; Kushner, P.J.; Brown, R. Canadian snow and sea ice: Historical trends and projections. Cryosphere 2018, 12, 1157-1176. [CrossRef]

40. Lakeman, T.R.; England, J.H. Late Wisconsinan glaciation and postglacial relative sea-level change on western Banks Island, Canadian Arctic Archipelago. Quat. Res. 2013, 80, 99-112. [CrossRef]

41. Ecosystem Classification Group. Ecological Regions of the Northwest Territories-Northern Arctic; Department of Environment and Natural Resources, Government of the Northwest Territories: Yellowknife, NT, Canada, 2013; pp. 1-157, ISBN 978-0-7708-0205-9.

42. Chander, G.; Markham, B.L.; Helder, D.L. Summary of current radiometric calibration coefficients for Landsat MSS, TM, ETM+, and EO-1 ALI sensors. Remote Sens. Environ. 2009, 113, 893-903. [CrossRef]

43. Crist, E.P.; Cicone, R.C. A physically-based transformation of thematic mapper data-The TM tasseled cap. IEEE Trans. Geosci. Remote Sens. 1984, GE-22, 256-263. [CrossRef]

44. Huang, C.; Wylie, B.; Yang, L.; Homer, C.; Zylstra, G. Derivation of a tasseled cap transformation based on Landsat 7 at-satellite reflectance. Int. J. Remote Sens. 2002, 23, 1741-1748. [CrossRef]

45. Kauth, R.J.; Thomas, G.S. The tasseled cap-A graphic description of the spectral-temporal development of agricultural crops as seen by Landsat. LARS Symp. 1976, 159, 41-51. 
46. Zeileis, A.; Leisch, F.; Hornik, K.; Kleiber, C. Strucchange: An R package for testing for structural change in linear regression models. J. Stat. Softw. 2002, 7, 1-38. [CrossRef]

47. R Core Team. R: A Language and Environment for Statistical Computing. R Foundation for Statistical Computing, Vienna, Austria, 2016. Available online: https:/ /www.R-project.org/ (accessed on 18 March 2018).

48. Bai, J.; Perron, P. Computation and analysis of multiple structural change models. J. Appl. Econ. 2003, 18, 1-22. [CrossRef]

49. Fraser, R.H.; Olthof, I.; Kokelj, S.V.; Lantz, T.C.; Lacelle, D.; Brooker, A.; Wolfe, S.; Schwarz, S. Detecting landscape changes in high latitude environments using Landsat trend analysis: 1. Visualization. Remote Sens. 2014, 6, 11533-11557. [CrossRef]

50. Kendall, M.G.; Stuart, A.S. Advanced Theory of Statistics; Charles Griffin and Company: London, UK, 1967; Volume 2.

51. Noh, M.-J.; Howat, I.M. Automated stereo-photogrammetric DEM generation at high latitudes: Surface extraction with TIN-based search-space minimization (SETSM) validation and demonstration over glaciated regions. GISci. Remote Sens. 2015, 52, 198-217. [CrossRef]

52. Anselin, L. Local indicators of spatial association-LISA. Geogr. Anal. 1995, 27, 93-115. [CrossRef]

53. Anselin, L. GeoDa: An introduction to spatial data analysis. Geogr. Anal. 2005, 38, 5-22. [CrossRef]

54. Burnham, K.P.; Anderson, D.R. Model Selection and Multimodel Inference: A Practical Information-Theoretic Approach, 2nd ed.; Springer: New York, NY, USA, 2002; ISBN 0-387-95364-7.

55. Zuur, A.F.; Ieno, E.N.; Elphick, C.S. A protocol for data exploration to avoid common statistical problems. Methods Ecol. Evol. 2010, 1, 3-14. [CrossRef]

56. Graham, M.H. Confronting multicollinearity in ecological multiple regression. Ecology 2003, 84, $2809-2815$. [CrossRef]

57. Littell, R.C.; Milliken, G.A.; Stroup, W.W.; Wolfinger, R.D.; Schabenberger, O. SAS for Mixed Models, 2nd ed.; SAS Institute Inc.: Carry, NC, USA, 2006; ISBN 978-1-59047-500-3.

58. Samelius, G.; Alisauskas, R.T.; Hines, J.E. Productivity of Lesser Snow Geese on Banks Island, Northwest Territories, Canada, in 1995-1998; Environment Canada Occasional Paper 115; Environment Canada, Canadian Wildlife Service: Edmonton, AB, Canada, 2008; pp. 3-33.

59. Price, L.W. Vegetation, microtopography, and depth of active layer on different exposures in subarctic alpine tundra. Ecology 1971, 52, 638-647. [CrossRef] [PubMed]

60. Fisher, J.P.; Estop-Aragones, C.; Thierry, A.; Charman, D.J.; Wolfe, S.A.; Hartley, I.P.; Murton, J.B.; Williams, M.; Phoenix, G.K. The influence of vegetation and soil characteristics on active-layer thickness of permafrost soils in boreal forest. Glob. Chang. Boil. 2016, 22, 3127-3140. [CrossRef] [PubMed]

61. Gornall, J.L.; Jonsdottir, I.S.; Woodin, S.J.; Van der Wal, R. Arctic mosses govern below-ground environment and ecosystem processes. Oecologia 2007, 153, 931-941. [CrossRef] [PubMed]

62. Woo, M.-K.; Guan, X.J. Hydrological connectivity and seasonal storage change of tundra ponds in a polar oasis environment, Canadian high Arctic. Permafr. Periglac. Process. 2006, 17, 309-323. [CrossRef]

63. Kokelj, S.V.; Jorgenson, M.T. Advances in thermokarst research. Permafr. Periglac. Process. 2013, 24, $108-119$. [CrossRef]

64. Suzuki, K.; Matsuo, K.; Yamakazi, D.; Ichii, K.; Iijima, Y.; Papa, F.; Yanagi, Y.; Hiyama, T. Hydrological variability and changes in the Arctic circumpolar tundra and the three largest pan-Arctic river basins from 2002 to 2016. Remote Sens. 2018, 10, 402. [CrossRef]

65. Brown, L.; Young, K.L. Assessment of three mapping techniques to delineate lakes and ponds in a Canadian high Arctic wetland complex. Arctic 2006, 59, 283-293. [CrossRef]

66. Liljedahl, A.K.; Boike, J.; Daanen, R.P.; Fedorov, A.N.; Frost, G.V.; Grosse, G.; Hinzman, L.D.; Iijma, Y.; Jorgenson, J.C.; Matveyeva, N.; et al. Pan-Arctic ice-wedge degradation in warming permafrost and its influence on tundra hydrology. Nat. Geosci. 2016, 9, 312-319. [CrossRef]

67. Riedlinger, D.; Berkes, F. Contributions of traditional knowledge to understanding climate change in the Canadian Arctic. Polar Rec. 2001, 37, 315-328. [CrossRef]

68. Ashford, G.; Catleden, J. Inuit Observations on Climate Change: Final Report; International Institute for Sustainable Development: Winnipeg, MB, Canada, 2001; pp. 1-31.

69. Ferguson, M.A.D.; Messier, F. Collection and analysis of traditional ecological knowledge about a population of Arctic tundra caribou. Arctic 1997, 50, 17-28. [CrossRef] 
70. Pekel, J.-F.; Cottam, A.; Gorelick, N.; Belward, A.S. High-resolution mapping of global surface water and its long-term changes. Nature 2016, 540, 418-422. [CrossRef] [PubMed]

71. French, H.M. The Periglacial Environment, 3rd ed.; John Wiley \& Sons: Chichester, UK, 2007; ISBN 978-0-47086-588-0.

72. Lachenbruch, A.H. Mechanics of Thermal Contraction Cracks and Ice-Wedge Polygons in Permafrost; Geological Society of America Special Papers; Geological Society of America: Boulder, CO, USA, 1962; Volume 70, pp. 1-66. [CrossRef]

73. Martin, A.F.; Lantz, T.C.; Humphreys, E.R. Ice wedge degradation and $\mathrm{CO}_{2}$ and $\mathrm{CH}_{4}$ emissions in the Tuktoyaktuk coastlands, Northwest Territories. Arct. Sci. 2018, 4, 130-145. [CrossRef]

2018 by the authors. Licensee MDPI, Basel, Switzerland. This article is an open access article distributed under the terms and conditions of the Creative Commons Attribution (CC BY) license (http://creativecommons.org/licenses/by/4.0/). 